\title{
PENGELOLAAN PROGRAM CORPORATE SOCIAL RESPONSIBILITY (CSR) PT PERTAMINA (Persero) RU III PLAJU
}

\author{
Oleh: Tim CSR PT Pertamina Refinery Unit III Plaju \\ Astri Rica Puspita, Agga Arista Barasani, Rahadiyand Aditya dkk ${ }^{1}$ \\ Astri.puspita@pertamina.com, agga.arista.b@mail.ugm.ac.id, \\ rahadiyand_aditya@yahoo.co.id
}

\begin{abstract}
ABSTRAK
Dewasa ini, tema Corporate Social Responsibility (CSR) menjadi bahasan yang makin hangat, baik di kalangan perusahaan, swasta, maupun masyarakat. Konsep CSR diejawantahkan oleh perusahaan menjadi pelbagai program pemberdayaan masyarakat yang tidak hanya berkutat pada kegiatan karitatif semata. Perusahaan-perusahaan seolah berlomba untuk menampilkan program-program CSR dalam versi terbaiknya. Konsep CSR tak lagi hanya dipandang sebagai persyaratan untuk memenuhi kewajiban perusahaan yang diatur di dalam perundangan, namun telah menjadi sebuah kesadaraan moral untuk berkontribusi dalam peningkatan kesejahteraan masyarakat. Dalam pengelolaan CSR, PT Pertamina RU III memiliki 3 program unggulan utama yang terbagi di wilayah ring I, ring II, dan ring III. Pada wilayah ring I, PT Pertamina RU III Plaju menggagas program Peningkatan Kesejahteraan untuk Masyarakat (PATRATURA). Program ini bergerak pada bidang pengelolaan sampah dari hulu berbasis masyarakat. Kemudian pada wilayah ring II, PT Pertamina RU III memiliki program Eco Green Fish Farming. Program tersebut fokus pada pengeloaan budidaya ikan air tawar. Terakhir, pada wilayah ring III, PT Pertamina RU III Plaju menginisiasi program Desa Mandiri Energi Pertamina yang terletak di Desa Merbau, Kecamatan Banding Agung, Kabupaten Oku Selatan.
\end{abstract}

Kata Kunci: CSR, Pemberdayaan, Kesejahteraan

\section{ABSTRACT}

Today, the theme of Corporate Social Responsibility (CSR) has become an increasingly warm discussion, both among companies, the private sector, and society. The concept of CSR is embodied by the company to be a variety of community empowerment programs that are not only focused on charitable activities. Companies seemed to be competing to show their best version of CSR programs. The concept of CSR is no longer only seen as a requirement to fulfill company obligations regulated in legislation, but has become a moral awareness to contribute to improving the welfare of society. In managing CSR, PT Pertamina RU III has 3 main superior programs which are divided into ring I, ring II, and ring III areas. In the ring I area, PT Pertamina RU III Plaju initiated the Community Welfare Improvement program (PATRATURA). This program is engaged in community-based upstream waste management. Then in the ring II area, PT Pertamina RU III has the Eco Green Fish Farming program. The program focuses on managing freshwater fish farming. Finally, in the ring III region, PT Pertamina RU III Plaju initiated the Pertamina Energy Independent Village program located in Merbau Village, Banding Agung District, South Oku District.

Keywords: CSR, Empowerment, Welfare

\footnotetext{
${ }^{1}$ Angger Wiyatmoko(Community Development Officer), Ita Puspitasari(Community Development Officer) dan Ratih Kumala Sari(Community Development Officer)
} 


\section{A. Pendahuluan}

Dewasa ini, tema Corporate Social Responsibility (CSR) menjadi bahasan yang makin hangat, baik di kalangan perusahaan, swasta, maupun masyarakat. Konsep CSR dijawantahkan oleh perusahaan menjadi pelbagai program pemberdayaan masyarakat yang tidak hanya berkutat pada kegiatan karitatif semata. Perusahaan-perusahaan seolah berlomba untuk proram-program CSR dalam versi terbaiknya. Hal tersebut tentu menjadi kabar baik bagi perkembangan CSR di Indonesia. Konsep CSR tak lagi hanya dipandang sebagai persyaratan untuk memenuhi kewajiban perusahaan yang diatur di dalam perundangan (oleh Carroll disebut sebagai obey the law), namun telah menjadi sebuah kesadaraan moral untuk berkontribusi dalam peningkatan kesejahteraan masyarakat atau bisa disebut sebagai philantropi responsibilities be good corporate citizen yang tujuan akhirnya adalah meningkatkan kualitas kehidupan semua $^{2}$.

Berkaitan dengan hal di atas, PT Pertamina Refinery Unit (RU) III Plaju menjadi bagian dari kesadaran moral tersebut. PT PT Pertamina RU III berkomitmen untuk melaksanakan program CSR berbasis pemberdayaan masyarakat, mulai dari tataran kebijakan, perencanaan, hingga implementasi program.Secara yuridis, kebijakan CSR PT Pertamina RU III Plaju merupakan turunan dari kebijakan CSR PT Pertamina (Corporate). Salah satu poin penting dalam kebijakan CSR PT PT

${ }^{2}$ Archie B. Caroll, Business and Society, Ethics and Stakeholder Management, Ohio: South Western College Publishing, Cincinnati, Third edition, 1996, hlm. 39
Pertamina RU III berbunyi "Melaksanakan CSR dengan konsep pembangunan berkelanjutan dengan prinsip Triple Bottom Lines, yakni profit (keuntungan ekonomi), people (kesejahteraan masyarakat), dan planet (keberlanjutan lingkungan hidup)". ${ }^{3} \mathrm{Hal}$ ini tentu semakin menegaskan bahwa kebijakan CSR PT PT Pertamina RU III tidak hanya sekadar untuk memenuhi kewajiban hukum (obey the law).

Program CSR PT PT Pertamina RU III Plaju tidak hanya menyasar pada masyarakat di wilayah ring 1 perusahaan, namun hingga di luar wilayah terdampak. ${ }^{4}$ Pada tahun 2017, PT PT Pertamina RU III memiliki binaan mulai dari wilayah ring 1, ring 2, hingga wilayah Desa Merbau, Oku Selatan yang jaraknya lebih dari $300 \mathrm{~km}$ dari perusahaan. Program-program yang diiniasi di pelbagai wilayah tersebut pun dirancang melalui perencanaan yang didasarkan pada permasalahan masyarakat, kebutuhan masyarakat, dan potensi wilayah. Selain itu, PT PT Pertamina RU III Plaju memiliki komitmen untuk mendampingi masyarakat binaan hingga mandiri (secara konseptual, masyarakat mandiri dapat dicapai dalam 5 tahun).

Pada tahun 2017, PT PT Pertamina RU III Plaju memiliki 3 program utama. Pada wilayah ring 1, PT PT Pertamina RU III menginisiasi program PATRATURA (Peningkatan

${ }^{3}$ Kebijakan Community Development dan Corporate Community Development PT Pertamina RU III Plaju tahun 2013, pdf.

${ }^{4}$ Pedoman Pengelolaan Kegiatan Tanggung Jawab Sosial dan Lingkungan/ Corporate Social Responsibility No. A-001/N00040/2013-S9, revisi ke-01 oleh Corporate Social Responsibilty, Corporate Secretary, PT. Pertamina (Persero), pdf. 
Kesejahteraan untuk Masyarakat). Secara sederhana, PATRATURA merupakan program pengelolaan sampah dari hulu berbasis masyarakat. Selanjutnya pada wilayah ring 2, PT PT Pertamina RU III Plaju menggagas program budidaya Ikan dengan nama Eco Green Fish Farming Program. Kemudian di wilayah ring 3 yakni di Desa Merbau, Oku Selatan, PT PT Pertamina RU III menggagas program Desa Mandiri Energi. Ketiga program utama tersebut dikelola dengan basis konsep pemberdayaan masyarakat yang dilakukan secara berkelanjutan.

\section{B. Peningkatan Kesejahteraan untuk Masyarakat (PATRATURA).}

\section{PATRATURA: Jaring Pengaman Sosial Berbentuk Bank Sampah}

Barangkali, adagium "mengubah sampah menjadi berkah" benar adanya. Kita mau tidak mau harus sepakat bahwa selama ini sampah dipandang sebelah mata karena selalu dianggap residu. Sebagai makhluk ekonomi, masyarakat tentu mempertimbangkan apa yang bisa ia dapatkan dari apa yang ia lakukan. Semakin besar keuntungan yang didapatkan maka semakin mudah masyarakat untuk digerakkan. Logika inilah yang hendak dipakai untuk mengubah pola pikir masyarakat terhadap sampah. Selama ini sampah oleh masyarakat selalu dianggap residu yang tidak memiliki nilai keuntungan.

Berangkat dari hal tersebut, PT Pertamina RU III Plaju menggagas program pengelolaan sampah dengan nama Patratura. Selaras dengan adagium "mengubah sampah menjadi berkah", Patratura diangkat untuk menciptakan kesadaran masyarakat tentang pentingnya sampah. Pola pikir masyarakat diubah dari yang sebelumnya menganggap sampah tidak bernilai menjadi bernilai ekonomis. Nilai ekonomis inilah yang menjadi titik tekan dari program ini. Melalui Patratura, masyarakat memiliki kesempatan untuk menabung dengan membuang sampah.

Jika pada umumnya bank sampah memiliki skema mengumpulkan, menabung, dan mendebit secara tunai, Patratura membentuk skema yang jauh lebih inovatif. Pada pelbagai macam literatur sosial, manusia pada dasarnya selalu disebut sebagai makhluk yang penuh dengan risiko. Tidak ada satupun manusia yang dapat menjamin eksistensinya di masa depan.

Dokter yang dianggap ahli dalam bidang kesehatan tidak selamanya sehat dan ada kalanya jatuh sakit bahkan mati. Pengusaha yang dianggap memahami pasar bisa saja gulung tikar. Penumpang pesawat yang diklaim sebagai penumpang dari transportasi paling aman boleh jadi sebelum mendarat mengalami kecelakan. Pada kenyataannya contoh-contoh di atas menampilkan manusia-manusia yang memiliki akses dan aset namun tetap tidak bisa lepas dari pelbagai macam risiko. Jika pada manusia yang memiliki akses dan aset pun tetap rentan terhadap risiko, lantas bagaimana dengan manusia yang tidak memiliki akses dan aset? Bagaimana dengan masyarakat yang memiliki kerentanan? Tentu saja mereka semakin rentan terhadap risiko.

Logika di atas dijadikan basis berpikir PT PT Pertamina RU III Plaju untuk mengkreasikan sebuah skema jaminan sosial melalui Patratura. Bagi 
PT Pertamina RU III, bank sampah dengan skema debit secara tunai tidak efektif untuk mereduksi risiko-risiko sosial bagi nasabahnya. Acap kali masyarakat tidak mampu membedakan kebutuhan dengan keinginan. Jika saldo nasabah bisa dicairkan dalam bentuk tunai, potensi-potensi penyalahgunaan uang itu semakin besar. Alih-alih untuk menjamin kebutuhan, uang dari tabungan bank sampah berpotensi untuk digunakan dalam pemenuhan barangbarang konsumtif belaka. Hal inilah yang hendak dihindari oleh PT PT Pertamina RU III Plaju. Secara teknis, saldo nasabah bank sampah hanya bisa dicairkan dengan metode reimbursement dengan minimal saldo Rp.100.000,-. Sementara itu, reimbursement hanya dapat dilakukan untuk transaksi kesehatan, pendidikan, listrik, air, dan kebutuhan pokok.

\section{Pembangunan Masyarakat dalam PATRATURA}

Bagi para ahli dalam studi Pembangunan Sosial, barangkali konsep pembangunan masyarakat (community development) cukup familiar dan selalu menjadi bahasan dari tiap diskusi-diskusi akademis. Takmengherankan karena memang konsep ini telah menjadi ruh dalam studi Pembangunan Sosial. Menginduk pada studi Pembangunan Sosial, PT PT Pertamina RU III Plaju pula menukil konsep ini untuk dijadikan ruh pada programprogram CSRnya.

Secara sederhana, programprogram CSR yang berkiblat pada konsep pembangunan masyarakat setidaknya harus terdiri dari empat jenis kegiatan, diantaranya pembangunan infrastruktur, kegiatan karitatif, peningkatan kapasitas kelompok sasaran, dan pemberdayaan. $^{5}$ Alih-alih berdiri sendiri, keempat kegiatan ini lebih bersifat komplementer dan saling mempengaruhi. Nihilnya salah satu dari keempat kegiatan ini bukan tidak mungkin akan menghambat keberhasilan program.

Komitmen PT PT Pertamina RU III Plaju untuk membuat sebuah program yang mampu memandirikan masyarakat binaan membawa PT Pertamina RU III Plaju pada sebuah kesadaran akan pentingnya sebuah program yang berkonsep pembangunan masyarakat. Oleh karenanya, Patratura digagas melalui proses yang cukup panjang agar mampu memenuhi kriteria program yang demikian. Berikut adalah Patratura dalam empat kegiatan pembangunan masyarakat:

\section{a. Pembentukan 4 Bank Sampah pada 2 Kelurahan dan 2 Desa}

Pada tahapan awal program Patratura, PT Pertamina RU III Plaju membentuk 4 kelompok bank sampah pada 2 kelurahan dan 2 desa di Kecamatan Plaju dan Kecamatan Banyuasin I. Masing-masing bank sampah terdiri dari 10 anggota pengurus yang kemudian menjadi pioner peduli lingkungan di masingmasing kelurahan atau desa.

\footnotetext{
${ }^{5}$ Tim PSDK, Membangun Tata Kelola Pengembangan Masyarakat (Community Development) Menurut Kriteria PROPER, Yogyakarta: Tim Departemen Pembangunan Sosial dan Kesejahteraan (PSDK), UGM, 2016.
} 
Pada tahap awal berdirinya bank sampah, masing-masing bank sampah memiliki 250 nasabah. Secara kumulatif, Patratura telah memiliki 1000 nasabah di tahap awal. Secara legal, keempat bank sampah binaan PT Pertamina RU III Plaju telah memiliki Surat Keputusan (SK) yang dikeluarkan oleh masing-masing kelurahan/desa.

\section{b. Inovasi dan Pembagian Ember Patrakomposter}

Kegiatan karitatif biasanya dimaknai sebagai pemberian bantuan langsung seperti barang habis pakai, tidak demikian dalam bantuan karitatif yang diberikan oleh PT Pertamina RU III. Merujuk pada konsep pembangunan masyarakat, PT Pertamina RU III mencoba memberikan bantuan karitatif yang berkaitan dan bersifat mendukung program-program besar Patratura. Dalam pelaksanannya, PT Pertamina RU III membagikan 1000 ember Patrakomposter untuk 1000 nasabah di 4 bank sampah binaan PT PT Pertamina RU III. Ember Patrakomposter merupakan ember pengolah sampah organik menjadi pupuk organik. Keunikan dari ember Patrakomposter ini terletak pada kemampuannya untuk menghasilkan pupuk organik padat dan pupuk organik cair dengan langkah yang sederhana. Kemudian, pupuk organik yang berhasil diolah oleh nasabah dapat ditabung di bank sampah atau dipakai secara pribadi untuk pemupukan tanaman.

\section{c. Patratura Membangun Sentra Pengolahan Pupuk Organik}

Dalam upayanya mereduksi sampah di masyarakat, kelahiran Patratura tidak hanya bertujuan untuk menjadi pipa yang menghubungkan sampah yang disetor oleh nasabah dengan pengepul besar. Patratura juga berupaya untuk meningkatkan nilai jual sampah yang disetor oleh nasabah. Pada tahap awal, Patratura membangun sentra pengolahan pupuk organik. Sentra pengolahan ini dimaksudkan untuk mengolah sampah organik masyarakat menjadi pupuk organik berbentuk cair maupun padat. Sentra pengolahan pupuk organik ini memiliki kelembagaan yang telah memiliki Surat Keputusan (SK) yang dikeluarkan oleh pihak kelurahan. Kelompok pengolahan pupuk ini menerima tabungan pupuk ember Patrakomposter dari bank sampah untuk kemudian diolah secara massal. Tidak hanya mengolah pupuk dari ember Patrakomposter, kelompok ini juga mengolah sampah daun dari masyarakat menjadi pupuk organik. 
d. Pelatihan bagi Pengurus Bank Sampah

Kegiatan selanjutnya yang diinisiasi oleh PT Pertamina RU III Plaju dalam rangkaian program Patratura adalah pelatihan pengurus bank sampah. Pelatihan ini telah dilaksanakan pada tanggal 16-20 Mei 2017 dan diikuti oleh kurang lebih 40 orang dari 4 desa/kelurahan binaan. Dalam pelatihan ini setidaknya peserta mendapatkan ilmu tentang cara pemilahan sampah, pengenalan bank sampah, pembukuan bank sampah, sistem bank sampah, cara pembuatan kerajinan dengan sampah organik. Luaran yang diharapkan dari pelatihan ini adalah peningkatan kapasitas bagi para pesertanya khususnya dalam bidang bank sampah. Selepas purna pelatihan, para peserta ini menjadi kader lingkungan di desa/kelurahan masing-masing untuk menularkan ilmunya melalui pelaksanaan bank sampah secara nyata.

\section{e. Pendampingan Berkelanjutan sebagai Wujud Pemberdayaan Masyarakat}

Jika ketiga kegiatan yang telah diuraikan di atas diikat dalam satu ikatan bersama maka terbentuklah skema pemberdayaan masyarakat. Salah satu upaya yang dapat ditempuh untuk menyimpul ketiganya adalah dengan melakukan pendampingan berkelanjutan. Pen-dampingan sejatinya harus di-lakukan sejak awal program agar program dapat berjalan efektif dan terarah. Dalam program Patratura, pendampingan dilaksanakan mulai pada saat sosialisasi program hingga program berjalan. Perlu diketahui bahwa pendampingan yang baik tentu pendampingan yang menciptakan kemandirian alih-alih ketergantungan. Oleh karenanya, pendampingan Patratura dilakukan secara hati-hati agar batasan antara mendampingi dengan mendikte tidak bias.

Dalam Patratura, aktoraktor kunci baik aktor positif maupun aktor negatifdi setiap wilayah binaan menjadi fokus dalam pendampingan. Pendamping harus senantiasa menjaga komunikasi dengan para aktor kunci. Hal ini dilakukan dengan sebuah pemahaman bahwa potensi keberhasilan ataupun potensi kegagalan program bisa saja muncul dari para aktor tersebut.

Meskipun demikian, sesuai dengan tujuan pemberdayaan masyarakat, pendampingan harus tetap menjaga kemandirian masyarakat. Meskipun program Patratura awalnya kental dengan nuansa top-down, pada pelaksanaannya lebih bersifat bottom-up. Hal ini terbukti dari partisipasi aktif kelompok binaan. Masing-masing kelompok binaan memiliki inisiatif untuk membentuk bank 
sampah sesuai dengan hasil musyawarah per bank sampah.

\section{f. Integrasi Program Patratura: Kelompok Kerajinan}

\section{1) Kelompok Sinar Fajar}

Sinar Fajarmerupakan kelompok binaan Pertamina RU III Plaju yang dibentuk pada awal tahun 2015. Kelompok Sinar Fajar merupakan kelompok binaan yang beranggotakan ibu-ibu dari Kelurahan Plaju Darat (salah satu ring 1 Pertamina RU III Plaju). Kelompok ini bergerak dalam pengolahan kerajinan sampah organik. Produk-produk yang mampu dihasilkan oleh kelompok ini antara lain:tas, tempat pensil, taplak meja, tirai, tatakan minum.

Sebagai bukti komitmen Pertamina RU III Plaju terhadap pembangunan berkelanjutan, Sinar Fajar pada tahun anggaran 2018 kembali diberikan pelatihan lanjutan untuk mengembangkan variasi produk. Tidak hanya untuk variasi produk saja namun pelatihan juga untuk meningkatkan kerapihan produk sehingga produk dapat bersaing dengan produk lain di pasaran yang bahan bakunya bukan berasal dari daur ulang. Dalam perkembangannya, pada tahun 2018 ini produk kelompok Sinar Fajar juga sudah masuk dalam pusat oleh-oleh Lenggok di Palembang. Tidak hanya itu, produk kerajinan daur ulang sampah ini juga sudah dipasarkan secara on line atau pun off line di Rumah Kreatif BUMN Palembang. Kerajinan daur ulang sampah yang diproduksi oleh kelompok Sinar Fajar ternyata juga cukup memiliki peminat. Harapan untuk kedepan nanti Kelompok Sinar Fajar memiliki etase sendiri dalam memasarkan kerajinan hasil produksi mereka.

Pada tahun ini Kelompok Sinar Fajar juga memiliki replikasi yakni dengan membina dan menyebarluaskan ilmu mereka dalam pengelolaan sampah anorganik menjadi suatu kerajinan yang tidak hanya memiliki nilai estetika namun juga memiliki nilai jual. Ilmu yang didapatkan dari pelatihan-pelatihan yang diikuti sebelumnya diaplikasikan pada kelompok ibu-ibu di Kelurahan Mariana Ulu. Dengan adanya kelompok replikasi ini diharapkan program pengelolaan sampah ini khususnya untuk kerajinan dalam naungan program Patratura dapat berkembang pada setiap tahunnya. 
2) Kelompok Melati

Kelompok ini bergerak
dalam pengolahan
keterampilan berbahan eceng
gondok. Sama halnya seperti
kelompok Sinar Fajar,
kelompok ini berada di
bawah naungan program
Patratura. Produk yang
mampu dihasilkan oleh
kelompok ini antara lain tas, sandal, kotak tisu, taplak meja, dan lain sebagainya. Pada tahun 2018, kelompok ini kembali diberikan pelatihan lanjutan oleh CSR Pertamina untuk meningkatkan kerapihan produk dan packaging.

$$
\text { Jika sebelumnya }
$$

penjualan produk hanya berdasarkan pesanan, pada tahun 2018 pemasaran produk kerajinan kelompok Melati sudah masuk dalam pusat oleh-oleh Lenggok di Palembang. Pemasaran secara on line pun sudah mulai dilakukan baik melalui media sosial seperti facebook ataupun melalui belanja.com dan rkb.co.id yang didukung oleh Rumah Kreatif BUMN Palembang.

Kelompok Melati juga aktif dalam mengikuti kegiatan pameran untuk lebih memperkenalkan produk eceng gondok. Selama ini eceng gondok dikenal sebagai hama namun berkat tangan terampil ibu-ibu Kelompok Melati mampu disulap menjadi peoduk yang memiliki nilai estetika dan nilai jual. Dalam perkembangannya, pada tahun 2018 Kelompok Melati memiliki kelompok replikasi di Kelurahan Plaju Ulu. Ilmu yang telah diperoleh selama ini tidak hanya digunakan untuk kepentingan sendiri namun juga disebarluaskan pada kelompok lain. Kelompok Melati mengaplikasikan ilmu yang dimiliki dengan membina dan mengajarkan cara membuat kerajinan dengan memanfaatkan hama eceng gondok pada kelompok karangtaruna dan ibu-ibu di Kelurahan Plaju Ulu.

\section{Eco Green Fish Farming Program}

Merujuk pada dokumen pemetaan sosial PT Pertamina RU III Plaju tahun 2015 yang dilakukan oleh instansi perguruan tinggi, salah satu rekomendasi program yang dihasilkan dalam pemetaan sosial adalah budidaya ikan lele. Secara kasat mata, lele memang menjadi komoditas yang potensial untuk dikembangkan mengingat kebutuhan lele di Palembang yang cukup besar. Hal ini ditangkap oleh PT Pertamina RU III sebagai potensi untuk mengembangkan masyarakat binaan. Pada tahun 2016, PT Pertamina RU III membina kelompok budidaya ikan air tawar "Bintang" di wilayah ring 2. Pada awal pembinaan, PT Pertamina RU III Plaju memberikan bantuan perbaikan infrastruktur berupa sumur, kamar mandi, dan jembatan penghubung jalan dengan kolam. 
Kemudian pada tahun 2017, PT Pertamina RU III meningkatkan kapasitas anggota kelompok melalui pelatihan pakan organik.

\section{Inovasi Filter Organik}

Kelompok Bintang mengalami beberapa hambatan yang kadang kala menyebabkan penurunan produksi bahkan gagal panen. Pertama, rendahnya $\mathrm{pH}$ ketika musim hujan tiba. Sistem pengairan Bintang yang masih mengandalkan air sumur dan tadah hujan tidak bisa menjamin kadar $\mathrm{pH}$ dalam kolam tetap normal. Perlu diketahui bahwa proses pemijahan dan pembesaran bibit membutuhkan $\mathrm{pH}$ normal (6-8 $\mathrm{pH})$. Disisi lain, kadar $\mathrm{pH}$ ketika musim hujan tiba berkisar antara 5-6 pH. Pada awalnya, untuk meningkatkan kadar $\mathrm{pH}$, kelompok Bintang harus mengendapkan air di dalam kolam selama 3 hari yang telah ditaburi kapur. Hal tersebut tentu menghambat proses produksi kelompok. Selama 3 hari, proses pemijahan maupun pembesaran tidak bisa dilakukan. Guna mengatasai persoalan tersebut, pada tahun 2017 CSR Pertamina RU III memberikan bantuan inovasi filter penetral $\mathrm{pH}$ organik. Filter ini memiliki keunikan pada penggunaan bonggol pisang sebagai salah satu komponen filter. Keunggulan bonggol pisang terletak pada kemampuannya untuk menetralkan $\mathrm{pH}$ air yang awalnya asam. Selain itu, bonggol pisang sebagai bahan organik tentu tidak memiliki dampak negatif terhadap lingkungan. Dengan filter ini, $\mathrm{pH}$ air dapat meningkat secara otomatis setelah melalui filter tanpa harus menunggu 3 hari lamanya. Hal ini tentunya sangat membantu kelompok Bintang dalam proses produksi ikan air tawar. Implikasinya, hasil panen kelompok ini mengalami peningkatkan karena pemijahan dan pembesaran dapat dilakukan setiap saat.

\section{Mewujudkan Kelompok Bintang sebagai Pusat Pelatihan Budidaya Ikan Air Tawar}

Pendampingan program secara intensif yang dilakukan oleh PT Pertamina RU III terbukti mampu membawa kemajuan bagi kelompok Bintang. Kemajuan kelompok dapat dilihat dari aspek peningkatan ekonomi. Hingga per Desember 2017, kelompok Bintang mengalami peningkatan omset sebesar $212 \%$, peningkatan hasil panen sebesar $243 \%$, dan peningkatan laba kelompok sebesar 298\%. Jika berkaca pada data tersebut, tak dimungkiri bahwa Kelompok Bintang perlahan menjadi kelompok percontohan budidaya ikan air tawar di Kota Palembang. Keberhasilan kelompok dalam pembibitan menjadi salah satu daya tarik kelompok lain untuk datang belajar menimba ilmu. Berangkat dari hal tersebut, rasarasanya tak berlebihan jika PT Pertamina RU III pada tahun 2018 menargetkan kelompok Bintang menjadi pusat pelatihan budidaya ikan air tawar di Kota Palembang.

\section{Diversifikasi Produk Olahan Pangan Berbahan Ikan Air Tawar}


Sebuah program pemberdayaan yang berhasil salah satunya ditandai dengan makin luasnya penerima manfaat dari program tersebut. Melalui program budidaya ikan air tawar, PT Pertamina RU III tidak hanya ingin memberikan dampak kepada kelompok budiaya ikan. Lebih dari itu, pada tahun 2018 PT Pertamina RU III hendak meningkatkan penerima manfaat dari program ini yang menyasar kepada ibu-ibu di sekitar kelompok Bintang. Program ini akan beranjak dari budidaya ikan menjadi pengolahan hasil pangan berbahan ikan sehingga tercipta diversifikasi produk. Dengan demikian, program budidaya ikan akan semakin memberikan manfaat bagi masyarakat sekitar secara masif.

\section{Inisiasi Budidaya Ikan Belida}

Kelangkaan Ikan Belida
manjadi hal yang cukup
memprihatinkan. Penangkapan ikan Belida terjadi secara terus menerus karena nelayan tergiur dengan tingginya harga ikan tesebut. Padahal pemerintah telah melindungi ikan Belida dengan mengeluarkan surat Keputusan Menteri Pertanian No.716/Kpts/UM/ 10/1980 dan Peraturan Pemerintah. Nomor 7 Tahun 1999 berisi tentang perlindungan terhadap ikan dari genus Chitala yakni dari spesies Chitala lopis atau dikanal dengan ikan Belida. Pemerintah Kota melalui Dinas Perikanan Kota Palembang menyatakan belum ada institusi, lembaga, atau pembudidaya yang secara khusus konsen terhadap konservasi Ikan Belida. Karakteristik Ikan Belida membuat pembudidaya yang mencoba untuk mengembangbiakannya sering mengalami kegagalan. Berangkat dari permasalahan tersebut, Pertamina sebagai perusahaan yang peduli terhadap lingkungan berupaya melestarikan Ikan Belida melalui program CSR yaitu, Program Inisiasi Konservasi Ikan Belida di wilayah Ring I PT Pertamina RU III Plaju.

Ikan Belida memiliki nama latin Chitala lopis atau dikenal dengan sebutan Knife Fish. Ikan ini merupakan ikan endemik air tawar di wilayah Sumatera Selatan khususnya di Aliran Sungai Musi. Ikan Belida tergolong ikan yang aktif mencari makan dimalam hari atau nocturnal. Ikan ini, dalam ekosistem sungai berperan sebagai predator atau pemangsa sesama. Makanan utama dari ikan ini yaitu ikan-ikan kecil dan udang. Ikan Belida dapat hidup di air yang dengan kadar oksigen yang cukup rendah atau dengan kondisi rawa-rawa. Kelangkaan ikan Belida erat kaitannya dengan bagaimana ikan Belida bereproduksi. Ada beberapa faktor yang mempengaruhi reproduksi ikan belida. Pertama, kondisi internal dari ikan Belida itu sendiri atau kondisi calon induk. Ukuran ideal ikan Belida untuk bereproduksi yaitu $42-51 \mathrm{~cm}$ dengan bobot $600-800$ gram/ekor. Jumlah telur yang ada pada indukan ikan Belida dapat dilihat dari ukuran fisiknya. Semakin besar ukuran ikan Belida, semakin banyak jumlah telurnya. Kedua, terdapat faktor yang mempengaruhi reproduksi ikan Belida adalah faktor eksternal seperti kondisi lingkungan. 
Kualitas air, ketersediaan pakan, musim kawin, dan metode pemijahan menjadi hal yang harus diperhatikan. Kualitas air untuk ikan Belida berkisar pada $\mathrm{pH} 6,5-7,5$ dengan suhu $20-30^{\circ} \mathrm{C}$. Kandungan oksigen dalam air yang digunakan untuk hidup ikan Belida berkisar pada 1,69 - 9,4 ppm. Ketersediaan makanan yang cukup serta waktu musim kawin juga ikut mempengaruhi proses reproduksi ikan Belida. Musim kawin ikan belida terjadi pada musim penghujan yaitu antara bulan November Februari. Ada dua cara untuk memijahkan ikan Belida, yaitu dengan cara semi alami dan pemijahan alami. Pemijahan semi alami sama seperti pemijahan ikan air tawar lainnya. Metode ini dilakukan dengan cara menginjeksi ovaprim dan human chorionic gonadotropin (hCG) ke dalam tubuh indukan. Hal ini dilakukan supaya ikan mengeluarkan ovarium dan spermatozoa. Setelah dilakukan injeksi, kemudian kedua indukan dimasukkan ke dalam kolam yang sama. Pemijahan alami ikan Belida dapat dilakukan dengan cara merekayasa kolam perkawinan seperti kondisi alam habitatnya. Ikan Belida di alam bereproduksi di daerah rawa-rawa atau kolam banjir dengan kedalaman 1,5 - 2 meter yang terdapat banyak akar atau batang pohon mati. akar dan batang tersebut digunakan ikan Belida untuk bersarang dan menempelkan telur-telurnya sampai menetas.

Berdasarkan pada permasalah tersebut, ditahun 2018 Pertamina mulai merintis budidaya ikan konservasi ikan Belida. Pertamina melakukan program ini berkerja sama dengan kelompok Unit Pembenihan Rakyat (UPR) Mulia I di Kelurahan Talang Bubuk. Lokasi ini masih berada di wilayah Ring I Pertamina RU III Plaju. UPR Mulia dipilih karena memikili pengalaman mengembangbiakkan dan membudidayakan beberapa ikan air tawar seperti Patin, Gurami, Betok, dan Lele. Pertamina bersama Kelompok Mulia I merintis budidaya dan konservasi ikan Belida didampingi oleh Dinas Perikanan Kota Palembang melalui penyuluh perikanan mulai dari tahap perencaan sampai pelaksanaan. Seiring berjalannya kegiatan ini, selain dengan penyuluh perikanan Pertamina juga berkonsultasi dengan Prodi Bididaya Perairan Universitas Muhamadiyah Palembang terkait dengan kendala dan permasalahan dalam budidaya ikan Belida. Kerja sama dengan stakeholder terkait sangat membantu dan diharapkan rintisan budidaya dan konservasi ikan Belida ini dapat berkembang.

\section{Desa Mandiri Energi Pertamina Cahaya di Kaki Langit Saruan}

Pada tahun 2017 tercatat terdapat 300 Desa yang berada di Sumatera Selatan merupakan daerah yang masih belum memperoleh aliran listrik dari pemerintah. Dusun Saruan Desa Merbau merupakan salah satunya. Desa Merbau merupakan satu dari 12 desa di Kecamatan Banding Agung Kabupaten Ogan Komering Ulu Selatan atau sering disebut OKU 
Selatan yang memiliki luas wilayah sebesar $10 \mathrm{KM}^{2}$. Terbagi menjadi 6 dusun dengan mayoritas penduduk bermata pencaharian petani dan pekebun.

Perbatasan Wilayah Desa

Merbau antara lain: wilayah Utara berbatasan dari Desa Karang Pendeta Kecamatan Margahaji, wilayah selatan berbatasan dari Desa Penantian Kecamatan Banding Agung, wilayah timur berbatasan dari Desa Sipatuhu 2 kecamatan Banding Agung dan wilayah barat berbatasan Desa Talang Baru Kecamatan Banding Agung.

Sejarah singkat Desa Merbau adalah dahulu pada zaman Belanda terdapat pembukaan lahan yang difokuskan pada dua daerah di wilayah sekitar Danau Ranau yaitu wilayah Sipatuhu yang nantinya akan dijadikan perkebunan Kopi dan daerah Gunung Raya yang akan dijadikan perkebunan Teh. Pada saat pembukaan lahan banyak penduduk yang didatangkan dari wilayah jawa. Sehingga sampai saat ini di wilayah tersebut mayoritas penduduk bersuku jawa.

Wilayah Desa Sipatuhu pada saat itu yang terlalu pada tahun 70-an terdapat pemekaran wilayah. Sampai saat ini terdapat 5 wilayah pemakaran termasuk wilayah sipatuhu sendiri yaitu Airupik, Merbau, Sidodadi, Sipatuhu 2 dan Sipatuhu. Desa Merbau memiliki 4 Dusun di awal antara lain : Dusun 2, Dusun 3, Dusun 4 dan Dusun 5, kemudian pemakaran pada Dusun 1 dan Dusun 6 sehingga menjadi 6 dusun.
Dusun Saruan terletak di wilayah Remote Area dengan kondisi demografi yang terletak di antara perbukitan menjadikan dusun ini kesulitan dalam memperoleh aliran listrik. Terdapat potensi berupa air terjun yang berketinggian 10-15 meter ini dapat dijadikan sumber Energi Baru Terbarukan (EBT) guna menyuplai kebutuhan energi. Masyarakat Dusun Saruan selama ini menikmati listrik dari pembangkit yang sudah dimulai sejak tahun 2011, diprakarsai oleh salah satu Dosen Teknik dari Universitas Muhammadiyah Palembang (UMP). Meskipun telah ada sentuhan dari pihak akademisi akan tetapi tenaga listrik menggunakan pembangkit ini masih belum maksimal dan kualitas listriknya belum stabil.

Pada tahun 2017 sudah dilaksanakan pembangunan Pembangkit Listrik Tenaga Mikro Hidro (PLTMH) oleh PT Pertamina RU III Plaju yang bekerjasama dengan Universitas Muhammadiyah Palembang (UMP) sebagai mitra teknis. Pembangunan turbin ini merupakan penyempurnaan dari turbin sebelumnya yang berkapasitas $5 \mathrm{kWh}$. Saat ini sudah ada PLTMH dengan kapasitas $10 \mathrm{kWh}$ yang digunakan untuk menerangi $32 \mathrm{KK}$ di Dusun Saruan.

\section{Pembangkit Listrik Tenaga Mikro Hidro (PLTMH) Desa Merbau}

Pemilihan jenis turbin air dalam PLTMH disesuaikan dengan debit air, dan ketinggian (head). Turbin air adalah mesin konversi energi yang berfungsi 
untuk merubah/mengkonversi energi potensial (head) yang dimiliki oleh air ke bentuk energi mekanik pada poros turbin. Turbin air crossflow adalah salah satu turbin air dari jenis turbin aksi (impulse turbine). Turbin tipe ini dibuat pertama kali di Eropa. Nama crossflow diambil dari kenyataan bahwa air melintasi kedua sudu gerak atau runner dalam menghasilkan putaran (rotasi). Sedangkan nama Banki (dari Hungaria) dan Mitchell (dari Austria) adalah nama ahli teknik yang mengembangkan prinsip-prinsip turbin tersebut yaitu turbin ini dilengkapi dengan pipa hisap, dan sebagai akibatnya daya yang dihasilkan turbin, proses kerja dan randemen turbin menjadi lebih baik. Turbin crossflow ini mempunyai arah aliran yang radial atau tegak lurus dengan sumbu turbin.

Turbin ini mempunyai alat pengarah sehingga dengan demikian celah bebas dengan sudu-sudu di sekeliling roda hanya sedikit. Karena itu pada keadaan beban penuh perputarannya roda terjadi sedikit kemacetan-kemacetan, yang menimbulkan sedikit tekanan lebih. Turbin crossflow terdiri dari tiga bagian utama yaitu roda jalan, alat pengarah dan rumah turbin. Dalam aplikasinya turbin crossflow baik sekali digunakan untuk pusat tenaga air yang kecil dengan daya kurang lebih $750 \mathrm{~kW}$.
Tinggi air jatuh yang bisa digunakan diatas $1 \mathrm{~m}$ sampai 200 $\mathrm{m}$ dan kapasitas antara $0,02 \mathrm{~m}^{3} / \mathrm{s}$ sampai $7 \mathrm{~m}^{3} / \mathrm{s}$.

\section{Kegiatan Pemberdayaan}

a. Modal Sosial Masyarakat

Dusun Saruan Merupakan salah satu dari 6 dusun yang ada di Desa Merbau, saat ini terdapat sekitar 37 KK yang tercatat merupakan penduduk Dusun Saruan. Jarak antara dusun saruan dengan Desa Merbau kisaran 2-3 $\mathrm{Km}$ dan hanya dapat dilalui dengan berjalan kaki atau mengendarai kendaraan roda dua. Mayoritas penduduk bermata pencaharian pekebun kopi dan lada. Jumlah penduduk yang tidak terlalu banyak menjadikan salah satu faktor tingkat keguyuban masyarakat masih cukup tinggi. Setiap kegiatan yang berhubungan dengan acara dusun akan dilakukan secara bersama-sama. Baik kegiatan keagamaan, kegiatan sosial maupun kegiatan lainnya.

\section{b. Partisipasi Aktif Masyarakat}

Pertamina telah melakukan beberapa kegiatan pembangunan di Dusun Saruan anatara lain: Pembangunan rumah turbin, instalasi listrik berupa tiang dan kabel, pengecoran jalan sejauh 3 KM dan pembangunan balai dusun. Keseluruhan kegiatan pembangunan ini dilakukan dengan melibatkan masyarakat langsung, secara teknis pembagian tugas dikordinir oleh 
Universitas Muhammadiyah

Palembang (UMP). Keterlibatan

masyarakat dimulai dari

melakukan diskusi dengan

masyarakat guna

mengidentifikasi kebutuhan dasar

masyarakat Desa Saruan, diskusi tersebut melibatkan masyarakat sebagai penerima manfaat, kemudian perwakilan Universitas Muhammadiyah Palembang (UMP) sebagai mitra teknis dan juga perwakilan dari perusahaan. Setelah mengidentifikasi kebutuhan dasar, maka mitra teknis dalam hal ini UMP melakukan secara detail pembangunan berdasarkan skala prioritas.

Pembangunan dilakukan berdasarkan skala prioritas, pertama, kegiatan yang dilakukan fokus pada pembuatan rumah turbin yang lebih aman yang disesuaikan dengan kapasitas yang pembangkit. Kedua, adalah pembangunan yang dilakukan adalah bangunan penunjang pembangkit seperti bendungan dan pipa air menuju pembangkit. Ketiga, pembuatan jalan dan jembatan menuju turbin. Keempat, pembuatan instalasi kabel dan tiang listrik menuju Dusun Saruan dan terakhir adalah pembangunan balai dusun.

Keseluruhan pembangunan yang dilakukan melibatkan masyarakat Dusun Saruan, hal ini dilakukan guna menciptakan rasa memiliki dan menjaga oleh setiap masyarakat Dusun Saruan. Salah satu partisipasi yang cukup penting adalah pada saat pembuatan instalasi pembangkit. Pada saat ini, terjadi pembagian pengetahuan

(Sharing Knowladge) dari akademisi, perwakilan perusahaan dan seorang ahli pembangkit kepada masyarakat. Kegiatan sharing knowladge dirasa penting karena nantinya masyarakatlah yang akan melakukan pengawasan dan perawatan pembangkit itu sendiri. Sehingga, apabila memerlukan perawatan rutin dapat langsung dilakukan oleh masyarakat tanpa harus berharap dengan pihak luar dan menjadikan program ini berlanjut dengan tanpa adanya pihak luar.

\section{c. Munculnya Institusi Sosial Baru}

Program Desa Mandiri Energi pada kegiatan Pembangkit Listrik Tenaga Mikro Hidro (PLTMH) bekerjasama dengan beberapa pihak, antara lain: Masyarakat, Pemerintah, Akademisi dan Perusahaan. Pembangunan ini melibatkan satu pihak dengan pihak lainnya. Bentuk kemitraan antar pihak dapat dilihat dari pengadaan alat dan kebutuhan bahan baku dilakukan oleh perusahaan, perhitungan konsep serta kebutuhan masyarakat dilakukan oleh akademisi, perawatan alat dan keberlanjutan pembangkit diawasi oleh masyarakat dan pemerintah sedangkan pada saat ekseskusi lapangan dilakukan 
oleh semua pihak secara gotong royong.

Guna menjaga dan merawat keberlanjutan pembangkit maka masyarakat melakukan inisiasi untuk membentuk sebuah institusi yang bertugas untuk merawat dan menjaga pembangkit. Institusi ini beranggotakan masyarakat Dusun Saruan yang berjumlah sesuai dengan masyarakat dusun yang menggunakan listrik, diketuai oleh Bapak Suyatno yang juga merupakan kepala dusun. Aktivitas kelompok ini terbagi menjadi 2 orang setiap harinya yang bertugas untuk menghidupkan pembangkit di sore hari dan mematikannya pada pagi hari. Petugas piket juga melakukan pemantauan pada wilayah aliran air sungai, hal ini dilakukan guna memastikan bahwa tidak ada kotoran yang mengganggu aliran air penyuplai tenaga pembangkit.

Jadwal rutin piket

"Kelompok Peduli Turbin" antara lain: Senin Bapak Hendri dan Sigit, Selasa Bapak Iring dan Bapak Atin, Rabu Bapak Junaidi dan Bapak Dedi, Kamis Bapak Yanto dan Bapak Jumadi, Jumat Bapak Slamet dan Winarno, Sabtu Bapak Sujono dan Bapak nadi dan Minggu Bapak Tukijo dan Bapak Lamidin. Setiap hari bertugas dua orang dan pembagian tugas disepakati oleh petugas disetiap harinya.

Institusi ini diberi nama "Kelompok Peduli Turbin", selain aktivitas piket, anggota juga melakukan iuran 20.000 setiap bulannya yang digunakan untuk biaya perawatan turbin. Sehingga, dengan adanya sumber dana tersebut masyarakat Dusun Saruwan tidak perlu menunggu bantuan pihak luar apabila terdapat kerusakan ringan atau biaya perawatan pembangkit. Biaya yang terkumpul bianya digunakan untuk membeli gumuk untuk menjaga agar setiap siku mesin yang bergerak tidak terjadi aus, selain itu juga biaya yang terkumpul digunakan untuk menyewa lahan yang dijadikan rumah turbin sebesar 700 ribu per tahun dan biaya akomodasi jika ada tamu yang berkunjung menuju turbin. Seluruh dana yang terkumpul di kelola secara transaparan dan penggunaannya di ketahui oleh seluruh anggota kelompok.

\section{d. Skema Pemberdayaan Kelompok}

Salah satu produk unggulan di Desa Merbau adalah produk berbahan dasar air nira, baik itu air niranya sendiri, gula torosan (gula merah) ataupun gula semut. Mayoritas masyarakat masih menjual produk air nira dan gula torosan (gula merah), Hal ini dikarenakan masyarakat lebih memilih jenis transaksi yang berbentuk cash and chary terhadap produk yang dihasilkan. Penjualan gula torosan (gula merah) lebih banyak dilakukan karena biasanya langsung dibeli oleh pengepul ke rumah warga, 
sehingga mayoritas masyarakat sudah merasa cukup dengan hanya membuat gula torosan(gula merah). Padahal secara hitung-hitungan di atas kertas, keuntungan yang dihasilkan tidak sebesar keuntungan yang diperoleh jika masyarakat memproduksi gula semut.

Masyarakat di Desa Merbau mayoritas sudah dapat mengelola air nira menjadi produk yang memiliki nilai jual tinggi, seperti gula aren torosan dan gula semut atau biasanya disebut brown sugar. Setelah hasil diskusi dengan masyarakat, kebutuhan saat ini adalah penambahan alat produksi seperti wajan, tungku, dan alat penunjang lainnya. Sehingga diputuskanlah kegiatan saat ini adalah pengadaan alat penunjang produksi. Harapannya dengan adanya pendambahan alat produksi masyarakat semakin meningkat dalam produksi dan meningkatkan perekonomian masyarakat.

Saat ini produksi gula semut masih dilakukan di setiap rumah warga, karena Desa Merbau belum memiliki tempat produksi yang ideal. Sehingga pada tahun 2018 bentuk kegiatan lain adalah pembuatan rumah produksi, sehingga pembuatan bisa di foksukan di satu tempat, kalaupun tidak minimal nantinya dalam pengepakan dan pemasaran gula semut terdapat di satu tempat yang cukup representatif. Sehingga kedepannya dapat juga menjadi etalase produk-produk lokal untuk Desa Merbau.

Produk unggulan lainnya di Desa Merbau adalah kopi. Mayoritas penduduk bermata pencaharian pekebun kopi, kegiatan pemberdayaan yang dilakukan saat ini adalah mendorong masyarakat untuk mengelola biji kopi menjadi bubuk kopi yang nilai jualnya lebih tinggi. Tahun ini kegiatan yang dilakukan dibagi menjadi dua wilayah yaitu di Dusun Saruan dan di Desa Merbau.

Pengadaan alat sangrai kopi dan penggiling kopi di Dusun Saruan menggunakan tenaga listrik, hal ini dilakukan agar dapat memanfaatkan listrik yang sudah dihasilkan oleh PLTMH. Sebelumnya masyarakat menyangrai kopi menggunakan tungku dan kayu sebagai bahan bakarnya, sehingga menimbulkan polusi. Untuk mesin penggiling kopi menggunakan mesin yang baru pertama kali dimiliki masyarakat, diharapkan pola penjualan produk untuk kopi di masyarakat berubah menjadi penjualan produk yang memiliki daya jual lebih tinggi.

Sedangkan untuk alat sangrai kopi dan penggiling kopi di Desa Merbau menggunakan tenaga disel, karena menurut masyarakat jika menggunakan listrik maka biaya produksi tidak seimbang dengan hasil penjualan. Selain pengadaan alat, tahun 2018 juga memberikan modal 
awal dan biaya stimulan untuk pengemasan produk.

Secara teknis nantinya, masyarakat akan diarahkan untuk memisahkan biji kopi yang merah dengan yang lainnya, dan kelompok akan menerima produk-produk terbaik untuk dijadikan bubuk kopi. Diharapkan dengan penggunaan biji kopi terbaik sebagai bahan pembuatan kopi, hasil dari bubuk kopi sendiri menjadi lebih baik dan berkualitas.

\section{E. Penutup}

Bahasan yang telah dipaparkan di atas dapat menjadi gambaran bahwa kegiatan CSR dewasa ini semakin berkembang dan mengutamakan prinsip kesejahteraan masyarakat. Seluruh program yang diiniasi oleh PT Pertamina RU III bermuara pada peningkatan kualitas hidup masyarakat, baik masyarakat wilayah ring I, ring II, maupun ring III, dan tentu saja masyarakat Indonesia secara umum.

Tidak dimungkiri bahwa kegiatan CSR memang membutuhkan waktu yang cukup panjang guna mencapai luaran yang diharapkan. Namun demikian, proses tersebut seharusnya dipahami oleh perusahaan sebagai sebuah obligasi moral. CSR bukan kegiatan seremonial yang selesai dalam waktu dekat. Oleh karenanya, komitmen dalam CSR artinya berkomitmen membina program paling tidak dalam jangka waktu 5 tahun. Sebagai penutup, PT Pertamina RU III akan terus berkomitmen dalam pengelolaan program CSR guna meningkatan kualitas kehidupan masyarakat.

\section{DAFTAR PUSTAKA}

Archie B. Caroll. 1996.Business and Society, Ethics and Stakeholder Management. Ohio: South Western College Publishing. Cincinnati. Third edition.

Kebijakan Community Development dan Corporate Community Development PT Pertamina RU III Plaju tahun 2013.

Pedoman Pengelolaan Kegiatan Tanggung Jawab Sosial dan Lingkungan/ Corporate Social Responsibility No. A-001/N00040/2013-S9, revisi ke01 oleh Corporate Social Responsibilty. Corporate Secretary. Pertamina.

Tim PSDK. 2016. Membangun Tata Kelola Pengembangan Masyarakat (Community Development) Menurut Kriteria PROPER. Yogyakarta: Tim Departemen Pembangunan Sosial dan Kesejahteraan (PSDK), UGM. 